\title{
A Review beyond the borders: Proteomics of microclonial black fungi and black yeasts
}

\author{
Gorji Marzban $^{1^{\star}}$, Donatella Tesei ${ }^{2}$, Katja Sterflinger ${ }^{2}$ \\ ${ }^{1}$ Department of Biotechnology, Plant Biotechnology Unit, VIBT, University of Life Sciences and Natural Resources, Vienna, Austria; \\ ${ }^{*}$ Corresponding Author: gorji.marzban@boku.ac.at \\ ${ }^{2}$ Department of Biotechnology, Austrian Center of Biological Resources and Applied Mycology, University of Life Sciences and \\ Natural Resources, Vienna, Austria
}

Received 8 March 2013; revised 11 April 2013; accepted 27 April 2013

Copyright (C) 2013 Gorji Marzban et al. This is an open access article distributed under the Creative Commons Attribution License, which permits unrestricted use, distribution, and reproduction in any medium, provided the original work is properly cited.

\begin{abstract}
Black microcolonial fungi and black yeasts are inhabitants of extreme environments like vulcanic, desert and polar regions, where they are exposed to enhanced temperature alterations and desiccation. They have developed, therefore, extraordinary biologic characteristics which are mainly based on the expression of proteins, however, these are rarely studied and known. The review article presented here is focused on the obstacles and solutions for the proteomic analyses of this very particular fungal species.
\end{abstract}

Keywords: Sample Preparation; Protein Solubilities; Extremophiles; Fungi

\section{INTRODUCTION}

Black micro-colonial fungi (MCF) and black yeasts are the most successful inhabitants of bare rock on the surfaces and inside of rock in desert-like regions [1] as well as ubiquitous dwellers of rock in other climatic zones [25]. Generally they exhibit high tolerance to stress and climate changes [6]. The cell composition of the MCFs consists majorly of lipids (e.g. mono-, di- and triacylglycerols, phosphotidilcholine, phosphatidylethanolamines, sterols, sterol ethers, phosphatidilrthanolamines, and free fatty acids) and pigments (e.g. melanins, carotenoids in colorless and brown-red formations) and a very complex and dense cell wall made of chitin, melanin and polysaccharides [7]. The cell wall is also the main obstacle in protein extraction from fungal biomass. Biologically, however, all the components are involved in a machinery, which enable the MCFs to be the most resistant eukaryotic organism on the Earth in an extremely stressful climate like deserts, volcanos or polar environments as well as in radioactive areas [8,9]. Experiments showed that theses terrestrial organisms are even capable of surviving the severe and hostile conditions in outer space over extended periods of time [10]. Some of these features might also be responsible for the human pathogenicity of some black yeasts like e.g. Exophiala dermatitidis.

The extreme stress tolerance of MCFs, however, is a virgin field of research. Except knowledge about their phenotypes, very slow growth rate and a complex structural composition, there are still very rare proteomic approaches generated about the system biology of black MCF $[11,12]$. The major challenge is to understand the expression, function/regulation of the entire set of genes/ proteins encoded by fungal genomes. Up to now full genomic sequences of only two strains of black fungi- $E x$ ophiala dermatitidis and Coniosporium apollinis-were done and are available in international databases (http://www.broad.mit.edu). The genomic data about MCFs are relatively rare because DNA extraction and purification for Next Generation Sequencing approaches has several obstacles. As mentioned above this is mainly the rigid cell wall and the high melanin content. Sequencing of further strains, however, is in progress. As compared to functional genomics approaches by transcriptome analysis (e.g. by microarrays), while a proteomics approach is more direct, transcriptomics investigates the all over change of gene expression at mRNA level. Proteomics leads to more reliable conclusions, since proteins are directly related to biological functions and phenotypes [13].

The lack of proteomic and genomic data for MCFs indeed indicates major analytical and methodological challenges and therefore there are only a few reports on the proteomic stress response of MCFs to different environmental factors $[11,12]$. The main bottleneck, however, 
is the sample preparation prior to analysis which is going far beyond the routine efforts.

\section{SAMPLE PREPARATION}

\subsection{Sample Homogenisation}

The fungus cell disruption is performed using different approaches by mechanical or enzymatic methodologies [14]. Since black fungi possess extraordinary rigid cell walls, the effective cell disruption is a crucial step for proteomic studies. The MCFs must be cultivated on a solid media or rigid background like cellulose sheets and the collection of the sample is, therefore, laborious and time consuming (Figure 1).

Mechanical cell disruption using glass beads in beating mills is, therefore, a preferred approach [15-19]. The mill can be also thermostatised at $4^{\circ} \mathrm{C}$ avoiding increased temperatures by heat generation and protein lysis due to intracellular proteases or denaturation. The milling can be also performed using mortar and pestle with liquid nitrogen [20]. Freeze drying can be also used as a disruptor before the milling procedure.

In this frame, the mechanical cell disruption can be combined with different homogenization buffers to enhance the disintegration of cell walls and inhibition of proteases activity [14]. Different concentrations of urea $(7-9 \mathrm{M})$ in combination with $2 \mathrm{M}$ thiourea are used as a strong chaotropic to re-solubilize the proteins in filamentous fungi [21]. Note that $7 \mathrm{M}$ urea is a saturated solution and any concentrations above this value enter the oversaturation level, which means that the buffer is only in liquid form at room temperature or higher. The ignoring of the saturation limit will end up in crystallization and drying of IPG-strips during the in-gel rehydration. Thiourea can also interfere with different protein determination procedures later on. Tris or phosphate buffers at 10 - $30 \mathrm{mM}$ were used to keep the $\mathrm{pH}$ constant and/or to be compatible with DIGE-labeling [22]. Further, the addition of $\mathrm{NaOH}$ at $0.1-1 \mathrm{M}$ can enhance the protein solubility and destabilize the cell wall tremendously [23]. As a non-ionic detergent CHAPS is used at the concentrations of $1 \%-4 \%$. It is recommendable to try different

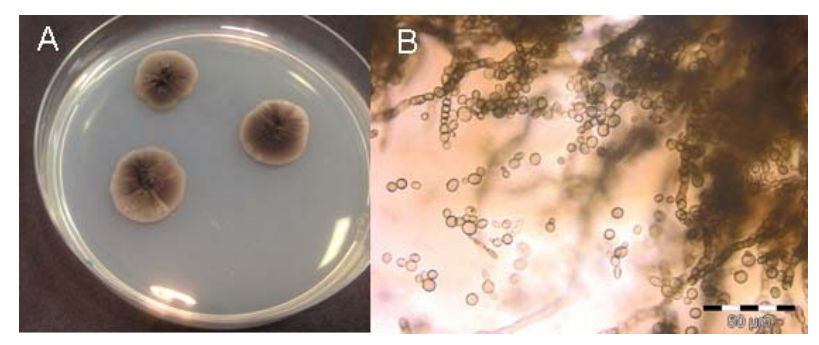

Figure 1. Colonies of Exophiala dermatitidis cultivated on solid media. Pictures taken by A) stereo microscope and B) optical microscope. concentrations of CHAPS for the most desirable protein yield, which is to be optimized case to case [14]. DTT and $\beta$-mercaptoethal were used as reducing agents in the homogenization buffer [24,25]. They reduce the disulfide bonds and enhance the protein solubility. Even ampholytes at a concentration of $0.5 \%$ to $0.8 \%$ are used for increased protein solubility, however it must be taken into consideration for the focusing procedure [26]. Proteases inhibitor cocktails or PMSF are added to the homogenization buffer to deactivate the strong fungal proteases and lysis of the proteins [10]. Addition of proteases inhibitors can potentially disturb the iso-electric focusing and can be skipped carefully if urea and/or thiourea are available in the homogenization buffer or the procedure is performed at $4^{\circ} \mathrm{C}$.

Enzymatic and chemical cell wall lysis was also used with less success for fungi samples [14]. Taken into consideration that black MCF are characterized by a more robust cell wall than filamentous fungi types, the solubilization of their proteins remain the main challenge for proteomic analyses. Therefore the selection of an appropriate method can enhance the initial protein amounts and must be optimized for each species.

\subsection{Protein Enrichment}

An optimal proteomic analyses needs $1-5 \mu \mathrm{g} / \mu \mathrm{L}$ of soluble proteins. The most popular strategy for protein enrichment remains precipitation using organic solvents like TCA or phenol. Several approaches are described and optimized by different researchers; however there are still no general protocols available to extract proteins from any given sample [27]. The combination of TCA and acetone is reported as effective and easy for precipitation of fungal proteins [28,29]. Other strategies like $100 \mathrm{mM}$ ammonium acetate in methanol were described also for fungal tissues [21]. However, TCA precipitation can disturb the iso-electric focusing even after multiple washing cycles using $80 \%$ acetone. The re-solubilization of protein pellet is significantly reduced after acidic precipitation, which affects the final protein yield. To avoid this problem the pellet must be dried very fast ( 1 - 2 minutes) before re-solubilization [14]. The main obstacles in protein extraction from black fungi are the high complexity of fungi matrices containing melanins, pigments, polysaccharides, chitin and lipids. Further, the fungal protein solubility is rather low and tends towards spontaneous precipitation. Both factors caused very low protein yield and high content of sample impurities which contain mainly melanins and various dark colored pigments interfering with protein determination and separation.

This might be also the reason for the lack of even one single proteomic study with black MCF or even with 
black yeasts [11]. The troubles caused by impurities could be overcome using different precipitation strategies for 2DE analysis [12]. However, the extracted amounts of the proteins were limited and could be first visualized by silver staining.

In order to increase the yield of the protein during extraction and precipitation different strategies and additives were needed (Table 1). A TCA/aceton/phenolbased precipitation protocol helped to separate the colored impurities from the protein extract before main protein extraction and precipitation. The protein pellet must then be re-solubilized by shaking with urea/thiourea for several hours. However, the yield of protein remained nearly the same, even by increased amounts of initial bi- omass. Since black MCFs are inhabitants of dry environments they comprise a protein repertory which is biologically active in water-free structures. This very unique characteristic implicates high abundance of less water-soluble proteins, which are susceptible to irreversible precipitation. It seems that the soluble proteins were at their solubility limits, so that their amount and concentrations could not be increased without the risk of a reprecipitation.

To increase the protein yield the addition of $2 \%$ SDS can be used during the homogenization before precipitation. As a second strategy $\mathrm{NaOH}$ was added to homogenization buffer during the milling of biomass. Both strategies could enhance the protein solubility signifi-

Table 1. Different sample preparation approaches to extract proteins from Exophilia dermatitis.

\begin{tabular}{|c|c|c|c|c|c|}
\hline Species & $\begin{array}{l}\text { Biomass } \\
(\mathrm{mg})\end{array}$ & Grinding methods & Homogenization buffer & $\begin{array}{l}\text { Solubilisation } \\
\text { buffer }\end{array}$ & $\begin{array}{l}\text { Average protein } \\
\text { concentration } \\
(\mu \mathrm{g} / \mu \mathrm{l})\end{array}$ \\
\hline $\begin{array}{l}\text { Exophiala } \\
\text { dermatitidis }\end{array}$ & $500-1000$ & $\begin{array}{l}\text { Mortar grinding under liquid } \\
\text { nitrogen followed cell disruption } \\
\text { using a glass bead beating system }\end{array}$ & $\begin{array}{l}50 \mathrm{mM} \text { Tris-Buffer } \mathrm{pH} 8.5,5 \mathrm{mM} \\
\text { EDTA, } 100 \mathrm{mM} \mathrm{KCl}, 1 \% \text { PVPP, } 30 \% \\
\text { Sucrose }\end{array}$ & $\begin{array}{l}7 \text { M Urea, } 2 \mathrm{M} \\
\text { Thiourea, } 4 \% \text { CHAPS }\end{array}$ & $\sim 1.5-2.0$ \\
\hline $\begin{array}{l}\text { Exophiala } \\
\text { dermatitidis }\end{array}$ & $1000-1500$ & $\begin{array}{l}\text { Mortar grinding under liquid } \\
\text { nitrogen followed cell disruption } \\
\text { using a glass bead beating system }\end{array}$ & $\begin{array}{l}50 \mathrm{mM} \text { Tris-Buffer } \mathrm{pH} 8.5,5 \mathrm{mM} \\
\text { EDTA, } 100 \mathrm{mM} \mathrm{KCl}, 1 \% \text { PVPP, } 30 \% \\
\text { Sucrose }\end{array}$ & $\begin{array}{l}4 \text { M Urea, } \\
2 \% \text { CHAPS }\end{array}$ & $\sim 0.80$ \\
\hline $\begin{array}{l}\text { Exophiala } \\
\text { dermatitidis }\end{array}$ & 700 & $\begin{array}{l}\text { Mortar grinding under liquid } \\
\text { nitrogen followed cell disruption } \\
\text { using a glass bead beating system }\end{array}$ & $\begin{array}{l}50 \mathrm{mM} \text { Tris-Buffer } \mathrm{pH} 8.5,5 \mathrm{mM} \\
\text { EDTA, } 100 \mathrm{mM} \mathrm{KCl}, 1 \% \text { PVPP, } 30 \% \\
\text { Sucrose, } 1 \mathrm{mM} \text { TCEP, } 2 \% \text { SDS }\end{array}$ & $\begin{array}{l}7 \mathrm{M} \text { Urea, } 2 \mathrm{M} \\
\text { Thiourea, } 1 \% \text { CHAPS, } \\
1 \mathrm{mM} \text { EDTA }\end{array}$ & $\sim 2.00$ \\
\hline $\begin{array}{l}\text { Exophiala } \\
\text { dermatitidis }\end{array}$ & $2 * 700$ & $\begin{array}{l}\text { Mortar grinding under liquid } \\
\text { nitrogen followed cell disruption } \\
\text { using a glass bead beating system }\end{array}$ & $\begin{array}{l}50 \mathrm{mM} \text { Tris-Buffer } \mathrm{pH} 8.5,5 \mathrm{mM} \\
\text { EDTA, } 100 \mathrm{mM} \mathrm{KCl}, 1 \% \mathrm{PVPP}, 30 \% \\
\text { Sucrose, } 1 \mathrm{mM} \text { TCEP, } 2 \% \text { SDS }\end{array}$ & $\begin{array}{l}300 \mathrm{mM} \text { Tris, } 7 \mathrm{M} \\
\text { Urea, } 2 \text { M Thiourea, } \\
4 \% \text { CHAPS }\end{array}$ & $0.80-1.70$ \\
\hline $\begin{array}{l}\text { Exophiala } \\
\text { dermatitidis }\end{array}$ & $2 * 700$ & $\begin{array}{l}\text { Mortar grinding under liquid } \\
\text { nitrogen followed cell disruption } \\
\text { using a glass bead beating system }\end{array}$ & $\begin{array}{l}50 \mathrm{mM} \text { Tris-Buffer } \mathrm{pH} 8.5,5 \mathrm{mM} \\
\text { EDTA, } 100 \mathrm{mM} \mathrm{KCl}, 1 \% \text { PVPP, } 30 \% \\
\text { Sucrose, } 1 \mathrm{mM} \text { TCEP, } 2 \% \text { SDS }\end{array}$ & $\begin{array}{l}300 \mathrm{mM} \text { Tris, } 7 \mathrm{M} \\
\text { Urea, } 2 \text { M Thiourea, } \\
4 \% \text { CHAPS }\end{array}$ & $0.50-0.80$ \\
\hline $\begin{array}{l}\text { Exophiala } \\
\text { dermatitidis }\end{array}$ & $4 * 700$ & $\begin{array}{l}\text { Mortar grinding under liquid } \\
\text { nitrogen followed cell disruption } \\
\text { using a glass bead beating system }\end{array}$ & $\begin{array}{l}50 \mathrm{mM} \text { Tris-Buffer } \mathrm{pH} 8.5,5 \mathrm{mM} \\
\text { EDTA, } 100 \mathrm{mM} \mathrm{KCl}, 1 \% \mathrm{PVPP}, 30 \% \\
\text { Sucrose, } 1 \mathrm{mM} \text { TCEP, } 2 \% \text { SDS }\end{array}$ & $\begin{array}{l}300 \mathrm{mM} \text { Tris, } 7 \mathrm{M} \\
\text { Urea, } 2 \text { M Thiourea, } \\
4 \% \text { CHAPS }\end{array}$ & $1.10-1.20$ \\
\hline $\begin{array}{l}\text { Exophiala } \\
\text { dermatitidis }\end{array}$ & 700 & $\begin{array}{l}\text { Mortar grinding under liquid } \\
\text { nitrogen followed cell disruption } \\
\text { using a glass bead beating system }\end{array}$ & $\begin{array}{l}0.5 \text { M Tris-Buffer pH8.5, } 5 \mathrm{mM} \text { EDTA, } \\
100 \mathrm{mM} \mathrm{KCl}, 1 \% \text { PVPP, } 30 \% \text { Sucrose, } \\
2 \% \text { SDS, } 4 \% \text { CHAPS }\end{array}$ & $\begin{array}{l}300 \mathrm{mM} \text { Tris, } 7 \mathrm{M} \\
\text { Urea, } 2 \text { M Thiourea, } \\
4 \% \text { CHAPS }\end{array}$ & $\sim 0.30$ \\
\hline $\begin{array}{l}\text { Exophiala } \\
\text { dermatitidis }\end{array}$ & 700 & $\begin{array}{l}\text { Mortar grinding under liquid } \\
\text { nitrogen followed cell disruption } \\
\text { using a glass bead beating system }\end{array}$ & $\begin{array}{l}0.5 \mathrm{M} \text { Tris-Buffer pH8.5, } 5 \mathrm{mM} \text { EDTA, } \\
100 \mathrm{mM} \mathrm{KCl}, 1 \% \text { PVPP, } 30 \% \text { Sucrose, } \\
2 \% \mathrm{SDS}\end{array}$ & $\begin{array}{l}300 \mathrm{mM} \text { Tris, } 7 \mathrm{M} \\
\text { Urea, } 2 \text { M Thiourea, } \\
4 \% \text { CHAPS }\end{array}$ & $\sim 0.40$ \\
\hline $\begin{array}{l}\text { Exophiala } \\
\text { dermatitidis }\end{array}$ & 700 & $\begin{array}{l}\text { Mortar grinding under liquid } \\
\text { nitrogen followed cell disruption } \\
\text { using a glass bead beating system }\end{array}$ & $\begin{array}{l}0.5 \mathrm{M} \text { Tris-Buffer pH8.5, } 5 \mathrm{mM} \text { EDTA, } \\
100 \mathrm{mM} \mathrm{KCl}, 1 \% \text { PVPP, } 30 \% \text { Sucrose, } \\
4 \% \mathrm{SDS}\end{array}$ & $\begin{array}{l}300 \mathrm{mM} \text { Tris, } 7 \mathrm{M} \\
\text { Urea, } 2 \text { M Thiourea, } \\
4 \% \text { CHAPS }\end{array}$ & $\sim 0.50-0.70$ \\
\hline $\begin{array}{l}\text { Exophiala } \\
\text { dermatitidis }\end{array}$ & 700 & $\begin{array}{l}\text { Mortar grinding under liquid } \\
\text { nitrogen followed cell disruption } \\
\text { using a glass bead beating system }\end{array}$ & $\begin{array}{l}50 \mathrm{mM} \text { Tris-Buffer pH8.5, } 5 \mathrm{mM} \\
\text { EDTA, } 100 \mathrm{mM} \mathrm{KCl}, 1 \% \mathrm{PVPP}, 30 \% \\
\text { Sucrose, } 2 \% \mathrm{SDS}+0.1-1 \mathrm{M} \mathrm{NaOH}\end{array}$ & $\begin{array}{l}300 \mathrm{mM} \text { Tris, } 7 \mathrm{M} \\
\text { Urea, } 2 \text { M Thiourea, } \\
4 \% \text { CHAPS }\end{array}$ & $2.5-3.0$ \\
\hline $\begin{array}{l}\text { Exophiala } \\
\text { dermatitidis }\end{array}$ & 700 & $\begin{array}{l}\text { Mortar grinding under liquid } \\
\text { nitrogen followed cell disruption } \\
\text { using a glass bead beating system }\end{array}$ & $\begin{array}{l}50 \mathrm{mM} \text { Tris-Buffer } \mathrm{pH} 8.5,5 \mathrm{mM} \\
\text { EDTA, } 100 \mathrm{mM} \mathrm{KCl}, 1 \% \text { PVPP, } 30 \% \\
\text { Sucrose, } 4 \% \mathrm{SDS}+0.1-1 \mathrm{M} \mathrm{NaOH}\end{array}$ & $\begin{array}{l}300 \mathrm{mM} \text { Tris, } 7 \mathrm{M} \\
\text { Urea, } 2 \text { M Thiourea, } \\
4 \% \text { CHAPS }\end{array}$ & $1.60-2.80$ \\
\hline
\end{tabular}


cantly. It seems that $\mathrm{NaOH}$ can disintegrate the cell membranes more effectively than other additives; however, the time of incubation must keep as short as possible avoiding protein degradation. Both additives will be separated from the proteins by the phenolic extraction, so that they cannot disturb the process of iso-electric focusing or interfere with LC-MS.

\section{PROTEIN SEPARATION}

\subsection{Gel-Based and Gel-Free Separation Techniques}

Three main technologies are applied to resolve the fungal proteome. The first and the most powerful is the two-dimensional electrophoresis, which seems to be also the method of choice for the separation and visualisation of proteins from black MCF and black yeasts. The methodology shows its power to separate a high number of proteins and visualize the alteration of protein patterns [11,12,30, Figure 2]. One-dimensional electrophoresis has been used in combination with mass spectrometry and despite its simplicity for the separation of the fungal proteome, leading to the discovery of novel proteins like malate dehydrogenase and peptydil prolyl cis-trtans isomerase [31,32] However, SDS-PAGE remains a qualitative methodology and the separation of the proteins in the bands is limited, resulting in a heterogenous band containig different proteins of identical molecular weight.

The gel-free LC-MS-based methodologies are still rarely used. Isobaric tag for relative and absolute quatita-

3

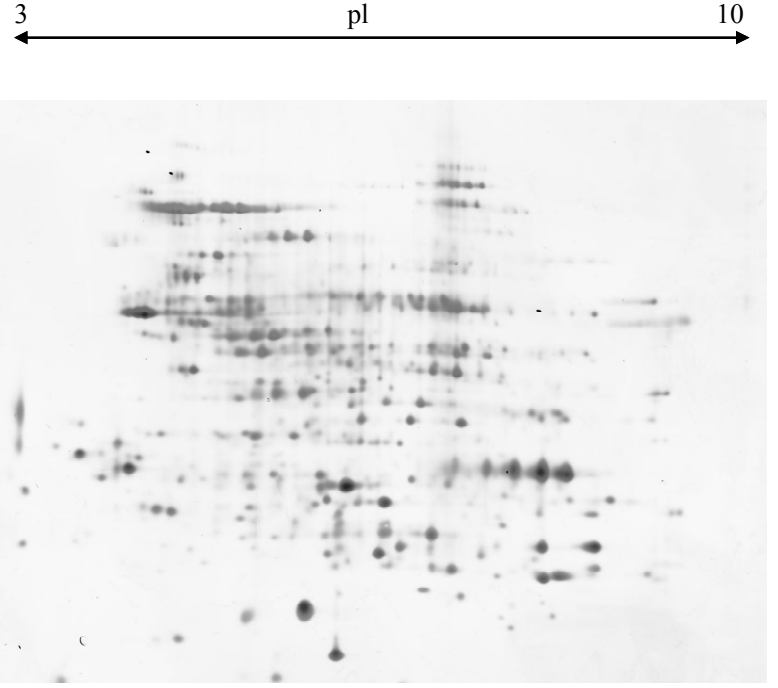

Figure 2. 2DE gel of an Exophiala dermatitis grown at optimal temperature of $37^{\circ} \mathrm{C}$ and extracted with homogenisation buffer containing $2 \%$ SDS and $0,2 \mathrm{M} \mathrm{NaOH}$. The proteins are focussed using Immobiline gel strips in pI range of 3 - 10 obtained from GE-Healthcare. The second dimension is performed in $10 \%$ polyacrylamide gel and stained by mass spectrometry compatible silver staining. tion (iTRAQ) in combination with MALDI-TOF/TOF MS was reported for the analysis of plasmamembrane ancored proteins in filamentous fungi, $[33,34]$. The application of gel-free techniques seems to enhance the efficient sepaparation and sensitivity of protein identification. However, gel-free protein separation approaches are still not conducted and implemented for black microclonial fungi. It seems that differential gel electrophoresis (DIGE) and LC-Based approaches ITRAQ are also bottlenecked by the sample preparation and protein yields. The main challenge herein remains the soluble protein contents in an appropriate buffer, which is compatible with the separation technique. Although, all the methodologies shows high potentials, their successful application is, therefore, still very limited.

\subsection{Data Analysis and Bioinformatics}

Proteomic analysis is exceptional for its capability of data generation. Even a simple 2D-gel provides information for at least some hundreds of proteins. Therefore, data analysis and implementation of bioinformatics gain a central role for the interpretation of obtained data.

The data generated in the field of black microclonial fungi and black yeasts are still rare. The lack of genomic sequence data makes the protein identification to an odyssee of homology searches in several available proteomic data bases like UniProt (http://www.uniprot.org), for plant pathogenic fungi Munich Information Center of Protein Sequence MIPS

(http://www.helmholtz-muenchen.de/en/ibis), the Sanger Institute Fungal Sequencing

(http://sanger.ac.uk/Projects/Fungi/), Central Aspergillus Database Repository (CADRE,

http://www.cadre-genomes.org.uk/) and FungalGenome (http://fungalgenomes.org/).

The more universal databases, however, gain on importance for the homology searches. These are to find at World-2DPAGE Repository from ExPASy

(http://world-2dpage.expasy.org/repository/), Proteomic IDEntifications database (PRIDE, www.ebi.ac.uk/pride/) and MASCOT (http://www.matrixscience.com). Despite of large depositories, huge amounts of data and publications, the available informations in the databases are infected with erroneous results, low-confidence protein identification and insufficient statistical evaluation [35]. HUPO Proteomic standard Initiative tries to bypass the disharmonies in experimental design and data generation by the guidance modules [36].

In the example of black microclonial fungi and the black yeasts, however, we must still wait for the completion of genomic sequence data by the novel technology of the next generation sequencing and annotations, which allow functional exploration of the protein expression of these unknown biological entities. 


\section{CONCLUSIONS}

The technological developments and construction of huge proteomics databases allow the exploration of system biologic processes and protein composition in various fungal species. However, the proteomics of black microcolonial fungi are still in the beginning due to limitations caused by the nature of species and protein solubility. Conventional approaches to extract the protein failed to enrich the protein even if the amounts of biomass was increased 2- to 3-fold. The ambitious and challenging issue could be bypassed by rigorous intervenetions like over average basic millieu and the use of SDS. The separation technologies are now capable of analysing the samples and extracts are compatible to different micro-technologies.

Updates in genomic seqencing methodologies and techniques empower biology to obtain full genomic sequence in less than two months. The main challenge will be then the functional annotation of the gene sequences and to extract the available data in the databases from erroneous information and weak data.

At the time being, the road is paved and open for conclusive experiments at physiologic as well as stress-tolerance biology. The future will show how MCFs cope with extreme environments and are able to maintain their survival and growth.

\section{ACKNOWLEDGEMENTS}

We thank the Austrian Science Fund (FWF-P24206) for the financial support of these studies.

\section{REFERENCES}

[1] Staley, J.T., Palmer, F. and Adams, J.B. (1982) Microcolonial fungi: Common inhabitants on desert rocks? Science, 215, 1093-1095.

doi:10.1126/science.215.4536.1093

[2] Wollenzien, U., De Hoog, G.S. Krumbein, W.E. and Urzi, C. (1995) On the isolation of microcolonial fungi occuring on and in marbia and other calcareous rocks. Science of Total Environments, 167, 287-297. doi:10.1016/0048-9697(95)04589-S

[3] Sterflinger, K. and Prillinger H.J. (2001) Molecular taxonomy and biodiversity of rock fungal communities in an urban environment (Vienna, Austria). Antonie Van Leewenhoek, 80, 275-286. doi:10.1023/A:1013060308809

[4] Ruibal, C., Platatas, G. and Bills, G.F. (2004) Isolation and characterization of melanized fungi from limestone formations in Mallorca. Mycological Progress, 4, 23-38. doi:10.1007/s11557-006-0107-7

[5] Selbmann, L., de Hoog, G.S., Mazzaglia, A., Friedmann, E.I. and Onofori, S. (2005) Fungi at the edge of life: Cryptendolithic black fungi from Antarctic desert. Studies in Mycology, 51, 1-32.

[6] Sterflinger, K., Krumbein, W.E., Lellau, T. and Rullköter,
J. (1999) Microbially mediated orange patination of rock surfaces. Ancient Biomolecules Journal, 3, 51-65.

[7] Gorbushina, A.A., Kollova, E.R. and Sherstneva, O.A. (2008) Cellular responses of microcolonial rock fungi to long term desiccation and subsequent rehydration. Sudies in Mycology, 61, 91-97. doi:10.3114/sim.2008.61.09

[8] Dadachova, E., Bryan, R.A., Huang, X., Moadel, T., Schweizer, A.D., Aisen, P., Nosanchuk, J.D. and Casadevall, A. (2007) Ionizing Radiation Changes the Electronic Properties of Melanin and Enhances the Growth of Melanized Fungi. PLoS ONE, 5, 1-13.

[9] Sterflinger, K., Tesei, D. and Zakharova, K. (2012) Fungi in hot and cold deserts with particular reference to microcolonial fungi. Fungi Ecology, 5, 453-462. doi:10.1016/j.funeco.2011.12.007

[10] Onofori, S., de la Torre, R., de Vera, J.-P., Ott, S., Zucconi, L., Selbmann, L., Scalzi, G., Venkateswaran, K.J., Rabbow, E., Sanchez, F.J. and Horneck, G. (2012) Survival of rockcoloniziong organisms after 1.5 years in outer space. Astrobiology, 12, 508-516. doi:10.1089/ast.2011.0736

[11] Isola, D., Marzban, G., Selbmann, L, Onofori, S., Laimer, M. and Sterflinger K. (2011) Sample preparation and 2$\mathrm{DE}$ procedure for protein expression profiling of black microclonial fungi. Fungal Biology, 10, 971-977. doi:10.1016/j.funbio.2011.03.001

[12] Tesei, D., Marzban, G., Zakharova, K., Isola, D., Selbmann, L. and Sterflinger, K. (2012) Alteration of protein patterns in black rock inhabiting fungi as a response to different temperatures. Fungal Biology, 116, 932-940. doi:10.1016/j.funbio.2012.06.004

[13] Bhadauria, V., Banniza, S., Wei, Y. and Peng, Y. (2009) Reverse genetic for functional genomics of phytopathogenic fungi and oomycetes. Comparative and Functional Genomics, 2009, 1-11. doi:10.1155/2009/380719

[14] Barreiro, C., García-Estrada, C. and Martín J.F. (2012) Proteomics Methodology Applied to the Analysis of Filamentous Fungi-New Trends for an Impressive Diverse Group of Organisms. In: Jeevan, K.P., Ed., Tandem Mass Spectrometry-Applications and Principles, InTech, New York, 127-160.

[15] Lim, D., Hain, P., Walsh, B., Bergquist, P. and Nevalainen, H. (2001) Proteins associated with the cell envelope of Trichoderma reesei: A proteomic approach. Proteomics, 1, 899-909. doi:10.1002/1615-9861(200107)1:7<899::AID-PROT899 $>3.0 . \mathrm{CO} ; 2-\#$

[16] Fernandez-Acero, F.J., Jorge, I., Calvo, E., Vallejo, I., Carbu, M., Camafeita, E., Lopez, J.A., Cantoral, J.M. and Jorrin, J. (2006) Two-dimensional electrophoresis protein profile of the phytopathogenic fungus Botrytis cinera. Proteomics, 1, 88-96. doi:10.1002/pmic.200500436

[17] Coumanns, J.V., Moens, P.D., Poljak, A., Al-Jaadi, S., Pereg, L. and Raftery, M.J. (2010) Plant-extract-induced changes in the proteome of the soil-borne pathogenic fungus Thielaviopsis basicola. Proteomics, 10, 1573-1591. doi:10.1002/pmic.200900301

[18] Jami, M.S., Garcia-Estrada, C., Barreiro, C., Cuadrado, A.A., Salehi-Najafabadi, Z. and Martin, J.F. (2010) The Penicillium crysogenum extracellular proteome. Conver- 
sionfrom a food-rotting strain to a versatile cell factory for white biotechnology. Molecular Cell Proteomics, 9, 2729-2744. doi:10.1074/mcp.M110.001412

[19] Yildirim, V., Ozcan, S., Becher, D., Bütter, K., Hecker, M. and Ozcengiz, G. (2011) Characterization of proteome alterations in Phanerochaete chrysosporium in response to lead exposure. Proteome Science, 9, 12. doi:10.1186/1477-5956-9-12

[20] Kniemeyer, O., Lessing, F., Scheibner, O., Hertweck, C. and Brakhage, A.A. (2006) Optimisation of a 2-D gel electrophoresis protocol fort he human-pathogenic fungus Aspergillus fumigatus. Current Genetics, 49, 178-189. doi:10.1007/s00294-005-0047-9

[21] Vödisch, M., Scherlach, K., Winkler, R., Hertweck, C., Braun, H.P., Roth, M., Haas, H., Werner, ER, Brakhage, A.A. and Kniemeyer, O. (2011) Analysis of the Aspergillus fumigatus reveals metabolic changes and the activetion of the pseurtin A biosynthesis gene cluster in responser to hypoxia. Journal of Proteome Research, 10, 2508-2524. doi:10.1021/pr1012812

[22] Kubitschek-Berreira, P.H., Curty, N., Neves, G.W., Gil, C. and Lopes-Bezerra, L.M. (2013) Differential proteomic analysis of Aspergillus fumigatus morphotypes reveals putative drug targets. Journal of Proteomics, 78, 522-534. doi:10.1016/j.jprot.2012.10.022

[23] Suh, M.J., Fedorova, N.D., Cagas, S.E., Hastings, S., Fleischmann R.D., Peterson, S.N., Perlin, D.S., Nierman, W.C., Pieper, R. and Momany, M. (2012) Development stagespecific proteomic profiling uncovers small lineage specific proteins most abundant in the Aspergillus fumigatos conidial proteome. Proteome Science, 10, 30. doi:10.1186/1477-5956-10-30

[24] Lu, X., Sun, J., Nimtz, M., Wissing, J., Zeng, A.P. and Rinas, U. (2010) The intra- an extracellular proteome of Aspergillus niger growing on defined medium with xylose or maltose as carbon substrate. Microbiologic Cell Factories, 20, 1-13.

[25] Oh, Y.T., Ahn, C.S., Kim, J.G., Ro, H.S., Lee, C.W. and Kim, J.W. (2010) Proteomic analysis of early phase of conidia germination in Aspergillus nidulans. Fungal Genetic and Biology, 47, 246-253. doi:10.1016/j.fgb.2009.11.002

[26] Sørensen, L.M., Lametsch, R., Andersen, M.R., Nielsen, P.V. and Frisvad, J.C. (2009) Proteome analysis of Aspergillus niger: Lactate added in starch-containing medium can increase production of mycotoxin fumunisin B2 by modifying acetyl-CoA metabolism. BMC Microbiology, 9, 255. doi:10.1186/1471-2180-9-255

[27] Marzban, G., Herndl, A., Maghuly, F., Katinger, H. and Laimer, M. (2008) Mapping of fruit allergens by 2D electrophoresis and immunodetection. Expert Review Proteomics, 5, 61-75. doi:10.1586/14789450.5.1.61
[28] Rizwan, M., Miller, I., Tasneem, F., Böhm, J., Gemeiner, M. and Razzazi-Fazeli, E. (2010) Proteome analysis of Aspergillus ochraceus. Mycotoxin Research, 26, 171-180.

[29] Razzazi-Fazeli, E., Rizwan, M., Mayrhofer, C. and Nöbauer, K. (2011) The use of proteomics as a novel tool in aflatoxin research. In: Aflatoxins - Biochemistry and Molecular Biology, InTech Publisher, New York.

[30] Zakharova, K., Tesei, D., Marzban, G., Dijksterhuis, J., Wyatt, T. and Sterflinger, K. (2012) Microcolonial fungi on rocks: A life in constant draught? Mycopathologia. doi:10.1007/s11046-012-9592-1

[31] Jorin-Novo, J.V., Maldonado, A.M., Echevarrira-Zomeno, S., Valledor, L., Castillejo, M.A., Curto, M., Valero, J., Sghaier, B., Donoso, G. and Redondo, I. (2009) Second generation proteomic techniques, an appropriate experimental design, and data analysis to fulfil MIAPE standards, increase plant proteome coverage and expand biological knowledghe. Journal of Proteomics, 72, 285-314. doi:10.1016/j.jprot.2009.01.026

[32] Dodds, P.N., Rafiqi, M., Gan, P.H. Hardham, A.R., Jones, D.A. and Ellis, J.G. (2009) Effects of biotrophic fungi and oomycetes: pathogenicity factors and triggers of host resistance. New Physiology, 183, 993-1000. doi:10.1111/j.1469-8137.2009.02922.x

[33] Bruneau, J.M., Magnin, T., Tagat, E., Legrand, R., Bernard, M. Diaquin, M., Fudali, C. and Latge, J.P. (2001) Proteome analysis of Aspergillus fumigatus identifies glycosylphosphatidylinositol-anchored proteins associated to the cell wall biosynthesis. Electrophoresis, 22, 28122823.

doi:10.1002/1522-2683(200108)22:13<2812::AID-ELPS 2812>3.0.CO;2-Q

[34] Ouyang, H., Luo, Y., Zhang, L. and Jin, C. (2010) Proteomic analysis of Aspergillus fumagatus total membrane protein identifies proteins associated with the glycoconjugates and cell wall biosynthesis using 2D LC-MS-MS. Molecular Biotechnology, 44, 177-189. doi:10.1007/s12033-009-9224-2

[35] Gonzalez-Fernandez, R., Prats, E. and Jorrin-Novo, J.V. (2010) Proteomics of plant pathogenic fungi. Journal of Biomedicine and Biotechnology, 1-30. doi:10.1155/2010/932527

[36] Taylor, C.E., Paton, N.W., Lilley, K.S., Binz, P.A., Julian, R.K., Jones, A.R., Zhu, W., Apweiler, R., Aebersold, R., Deutsch, E.W., Dunn, M.J., Heck, A.J., Leitner, A., Macht, M., Mann, M., Martens, L., Neubert, T.A., Patterson, S.D., Ping, P., Seymour, S.L., Souda, P., Tsugita, A., Vandekerckhove, J., Vondriska, T.M., Whitelegge, J.P., Wilkins, M.R., Xenarios, I., Yates, J.R. and Hermjakob, H. (2007) The minimum information about a proteomic experiment (MIAPE). Nature Biotechnology, 78, 887-893. doi:10.1038/nbt1329 